\section{Physical Activity,}

Cardiorespiratory Fitness and Body Mass Index as Predictors of Substantial Weight Gain and Obesity

\author{
The Canadian Physical Activity Longitudinal Study
}

\author{
Susan E. Brien, $\mathrm{PhD}^{1}$ \\ Peter T. Katzmarzyk, PhD ${ }^{1,2}$ \\ Cora L. Craig, $\mathrm{MSc}^{3}$ \\ Lise Gauvin, $\mathrm{PhD}^{4}$
}

\section{ABSTRACT}

Background: Obesity is a growing health issue in Canada and the identification of the determinants of obesity is important for the development of prevention strategies. The purpose of this investigation was to determine the relationships between physical activity, cardiorespiratory fitness, body mass index (BMI), and the development of future obesity.

Methods: The sample included 459 adults (18+y; 223 men, 236 women) from the Canadian Physical Activity Longitudinal Study (PALS; 2002-04). Data on physical activity, smoking, alcohol consumption, $\mathrm{BMI}$, and cardiorespiratory fitness $\left(\mathrm{VO}_{2 \max }\right)$ were collected in 1981 and 1988. The mean BMI, physical activity, and $\mathrm{VO}_{2 \max }$ were calculated across the 1981 and 1988 measures. Self-reported height and weight were collected in the 200204 survey, and participants were classified as overweight (BMI 25 to $29.9 \mathrm{~kg} / \mathrm{m}^{2}$ ) or obese $\left(\mathrm{BMI} \geq 30 \mathrm{~kg} / \mathrm{m}^{2}\right)$. Logistic regression was used to predict overweight, obesity or substantial weight gain (10 kg or more) in 2002-04, controlling for age, sex, smoking and alcohol use.

Results: Higher $\mathrm{VO}_{2 \max }$ in 1981-88 was associated with lower odds of obesity in 2002-04 $(\mathrm{OR}=0.87 ; 95 \% \mathrm{Cl}: 0.76-0.99, \mathrm{p}<0.05)$, and higher $\mathrm{BMI}$ in 1981-88 was associated with higher odds of obesity in 2002-04 $(1.84 ; 1.52-2.20, \mathrm{p}<0.0001)$. In women, higher $\mathrm{VO}_{2 \max }$ $(0.82 ; 0.72-0.93)$ resulted in lower odds of a $10 \mathrm{~kg}$ weight gain.

Conclusions: The results indicate that cardiorespiratory fitness and previous BMI are important predictors of future weight gain and obesity, and should be incorporated in strategies to identify individuals at increased risk of obesity.

MeSH terms: Obesity; weight gain; body mass index; physical fitness; longitudinal survey

La traduction du résumé se trouve à la fin de l'article.

1. School of Kinesiology and Health Studies, Queen's University, Kingston, ON

2. Department of Community Health and Epidemiology, Queen's University

3. Canadian Fitness and Lifestyle Research Institute, Ottawa, ON

4. Département de médecine sociale et préventive et Groupe de recherche interdisciplinaire en santé, Université de Montréal, Montréal, OC

Correspondence: Peter T. Katzmarzyk, School of Kinesiology and Health Studies, Queen's University, Kingston, ON K7L 3N6, Tel: 613-533-6000, ext. 75210, Fax: 613-533-2009, E-mail: katzmarz@post.queensu.ca

Acknowledgement of funding: Funded by a grant from the Social Sciences and Humanities Research Council of Canada and the Canadian Institutes of Health Research (Strategic Joint Initiative Grant on Society, Culture and the Health of Canadians II Grant No. 839-2000-1032). The 1981 Canada Fitness Survey was supported by Fitness and Amateur Sport (now the Physical Activity Unit of Health Canada) and the 1988 Campbell's Survey on Well Being was funded by Fitness and Amateur Sport, the National Health Research and Development Program of Health Canada (Grant No. 6606-3217-46), and the Campbell Soup Company Ltd. S.E.B. is funded by a post-doctoral fellowship from the Canadian Heart Health Surveys Follow-up Study, which is funded through a New Emerging Team grant from the Canadian Institutes of Health Research and the Heart and Stroke Foundation of Canada.
T he prevalence of obesity among Canadians is increasing. The average body mass index (BMI; $\mathrm{kg} / \mathrm{m}^{2}$ ) of adults has increased from approximately 25 to 27 between 1978-79 and 2004, while the prevalence of obesity (BMI $\geq 30.0 \mathrm{~kg} / \mathrm{m}^{2}$ ) has increased from $13.8 \%$ to $23.1 \%$ over the same period. ${ }^{1}$ These changes in obesity are placing an increasing burden on medical care and are taking a toll on public health. ${ }^{2,3}$

As obesity becomes a growing health issue, it is important that the determinants and correlates of unhealthy body weights in the Canadian context be identified in order to develop appropriate prevention strategies. The increase in obesity is due for the most part to an energy imbalance where the amount of energy being consumed by an individual is greater than the amount of energy being expended. ${ }^{4}$ Although an inverse relationship between leisure time physical activity and obesity has been demonstrated, ${ }^{5,6}$ it remains to be determined whether physical activity prevents the development of obesity. It is likely that among those who do not match food consumption to low activity levels, the constant energy imbalance leads to weight gain. Thus, we hypothesize that those who are physically inactive are more likely to be overweight or obese later in life.

Physical activity is a behaviour which is difficult to measure and is often misreported. On the other hand, physical fitness, a physiologic condition that reflects habitual physical activity levels, ${ }^{7}$ can be objectively measured. Thus, the purpose of this investigation was to determine the relationships between physical activity, cardiorespiratory fitness and the development of overweight and obesity over 20 years in a prospective cohort of Canadians. Given that indicators of obesity are relatively stable traits over time ${ }^{8}$ we also hypothesized that BMI would also predict the development of obesity.

\section{METHODS}

\section{Data source}

The Physical Activity Longitudinal Study (PALS) is a 20-year follow-up study of people who originally participated in the 1981 Canada Fitness Survey (CFS) and the 1988 Campbell's Survey of Well Being in Canada (CSWB). ${ }^{9}$ 


\section{Study sample}

The PALS cohort consists of approximately 4,900 eligible individuals aged 15 years and older in 2002-04, and was based on the CFS/CSWB cohort. The follow-up phase was quite successful, yielding a $90 \%$ follow-up rate, of which approximately $20 \%$ refused to participate and about $10 \%$ were deceased, whereas full data were available for approximately 2,500 people. ${ }^{9}$ When the sample was further restricted to those at least 18 years of age with complete data at baseline, the sample included 459 adult participants $(223$ men and 236 women). PALS was approved by the Faculty of Medicine's Ethics Review Board of the University of Montreal. All participants provided their informed consent to participate in the follow-up survey.

\section{Exposure variables}

Measured heights and weights were collected during household visits in 1981 and 1988 using standardized equipment and procedures, ${ }^{10}$ and the BMI was calculated. Estimated $\mathrm{VO}_{2 \max }\left(\mathrm{ml} \mathrm{kg}^{-1} \cdot \mathrm{min}^{-1}\right)$ was used as a measure of cardiorespiratory fitness in 1981 and 1988 using a modified version of the Canadian Aerobic Fitness Test. ${ }^{10}$ Leisure-time physical activity levels were assessed using a questionnaire modelled after the Minnesota Leisure Time Physical Activity Questionnaire, which collected information about physical activity over the previous 12 months. A list of physical activities was provided and respondents indicated the number of occasions and the average duration of the activity bouts. Average daily leisure-time activity energy expenditure (AEE) was calculated as follows:

\section{$\operatorname{AEE}\left(\mathrm{kcall}^{-1} \mathrm{kday}^{1}\right)=\Sigma\left[\left(\mathrm{N}_{\mathrm{i}} \times \mathrm{D}_{\mathrm{i}} \times \mathrm{METS}_{\mathrm{i}}\right) / 365\right]$}

where $\mathrm{N}_{i}$ is the number of times the activity was performed, $\mathrm{D}_{\mathrm{i}}$ was the average duration in hours of the activity, and METS was $_{i}$ the estimated energy cost of the activity $\left(\mathrm{kcal}^{\mathrm{kg}}{ }^{-1} \mathrm{hr}^{-1}\right)$.

The mean BMI, physical activity and cardiorespiratory fitness levels for the 1981 and 1988 measurements were determined and used in all analyses.

\section{Outcome assessment}

Self-reported height and weight were used to calculate BMI at follow-up in

TABLE I

Characteristics of Sample by Sex and Survey Year

\begin{tabular}{|c|c|c|c|c|}
\hline & 1981 & 1988 & $\begin{array}{c}\text { Mean } 1981 \\
\text { and } 1988\end{array}$ & 2002-2004 \\
\hline \multicolumn{5}{|l|}{ Overall $(n=459)$} \\
\hline Mean age (years, SD) & $32.8(9.6)$ & $39.7(9.6)$ & - & $55.3(9.6)$ \\
\hline Mean BMI $\left(\mathrm{kg} / \mathrm{m}^{2}, \mathrm{SD}\right)$ & $23.2(3.1)$ & $24.4(3.3)$ & $23.8(3.1)$ & $25.6(3.6)$ \\
\hline$\%$ Overweight and Obese $\left(\mathrm{BMI} \geq 25 \mathrm{~kg} / \mathrm{m}^{2}\right)$ & 27.0 & 41.3 & - & 53.1 \\
\hline$\%$ Overweight $\left(25 \mathrm{~kg} / \mathrm{m}^{2} \leq \mathrm{BMl}<30 \mathrm{~kg} / \mathrm{m}^{2}\right)$ & 25.3 & 36.5 & - & 42.3 \\
\hline$\%$ Obese $\left(\mathrm{BMI} \geq 30 \mathrm{~kg} / \mathrm{m}^{2}\right)$ & 1.9 & 5.0 & - & 10.4 \\
\hline Mean Physical Activity (kcal.kg-1. day ${ }^{-1}, \mathrm{SD}$ ) & $2.1(2.4)$ & $2.4(2.0)$ & $2.3(1.7)$ & $2.1(2.1)$ \\
\hline 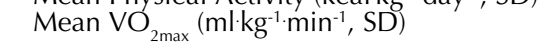 & $37.9(8.3)$ & $39.2(6.1)$ & $38.5(6.8)$ & - \\
\hline \multicolumn{5}{|l|}{ Men $(n=223)$} \\
\hline Mean age (years, SD) & $32.8(9.8)$ & $39.6(10.0)$ & - & $55.2(9.8)$ \\
\hline Mean BMI $\left(\mathrm{kg} / \mathrm{m}^{2}, \mathrm{SD}\right)$ & $24.1(2.9)$ & $25.3(3.0)$ & $24.7(2.9)$ & $26.1(3.1)$ \\
\hline$\%$ Overweight and Obese $\left(\mathrm{BMI} \geq 25 \mathrm{~kg} / \mathrm{m}^{2}\right)$ & 35.2 & 53.5 & - & 63.0 \\
\hline$\%$ Overweight $\left(25 \mathrm{~kg} / \mathrm{m}^{2} \leq \mathrm{BMl}<30 \mathrm{~kg} / \mathrm{m}^{2}\right)$ & 32.7 & 48.2 & - & 52.9 \\
\hline$\%$ Obese $\left(\mathrm{BMI} \geq 30 \mathrm{~kg} / \mathrm{m}^{2}\right)$ & 3.1 & 5.8 & - & 9.2 \\
\hline Mean Physical Activity (kcal kg-1. day ${ }^{-1}, \mathrm{SD}$ ) & $2.6(2.8)$ & $2.8(2.3)$ & $2.7(2.0)$ & $2.2(2.3)$ \\
\hline Mean $\mathrm{VO}_{2 \max }\left(\mathrm{ml} \cdot \mathrm{kg}^{-1} \cdot \mathrm{min}^{-1}, \mathrm{SD}\right)$ & $43.4(7.3)$ & $42.2(5.3)$ & $42.8(5.7)$ & - \\
\hline \multicolumn{5}{|l|}{ Women $(n=236)$} \\
\hline Mean age (years, SD) & $32.8(9.4)$ & $39.7(9.3)$ & - & $55.4(9.4)$ \\
\hline Mean BMl $\left(\mathrm{kg} / \mathrm{m}^{2}, \mathrm{SD}\right)$ & $22.3(2.9)$ & $23.6(3.4)$ & $23.0(3.0)$ & $25.1(3.9)$ \\
\hline$\%$ Overweight and Obese $\left(B M I \geq 25 \mathrm{~kg} / \mathrm{m}^{2}\right)$ & 19.1 & 29.7 & $2.0(3.0)$ & 43.6 \\
\hline$\%$ Overweight $\left(25 \mathrm{~kg} / \mathrm{m}^{2} \leq \mathrm{BMl}<30 \mathrm{~kg} / \mathrm{m}^{2}\right)$ & 18.2 & 25.4 & - & 32.2 \\
\hline$\%$ Obese $\left(\mathrm{BMI} \geq 30 \mathrm{~kg} / \mathrm{m}^{2}\right)$ & 0.85 & 4.2 & - & 11.4 \\
\hline Mean Physical Activity (kcal kg-1. day-1, SD) & $1.7(1.7)$ & $2.0(1.5)$ & $1.9(1.3)$ & $1.9(1.9)$ \\
\hline Mean $\mathrm{VO}_{2 \max }\left(\mathrm{ml}^{\mathrm{kg}}{ }^{-1} \mathrm{~min}^{-1}, \mathrm{SD}\right)$ & $32.6(5.3)$ & $36.3(5.4)$ & $34.4(5.0)$ & - \\
\hline
\end{tabular}

SD, Standard Deviation; BMI, body mass index.

\section{TABLE II}

Descriptive Statistics for Those Who Gained $10 \mathrm{~kg}$ or More Between 1981-88 and 2002-04

$\begin{array}{lccc} & \begin{array}{c}\text { Overall } \\ (\mathbf{n = 1 1 7 ; ~ 2 5 . 6 \% )}\end{array} & \begin{array}{c}\text { Men } \\ (\mathbf{n = 5 9 ;} \mathbf{2 6 . 6} \%)\end{array} & \begin{array}{c}\text { Women } \\ (\mathbf{n = 5 8 ; ~ 2 4 . 6 \% )}\end{array} \\ \text { Average weight gain (kg, SD) } & 14.8(4.5) & 13.9(3.3) & 15.6(5.3) \\ \text { Lower - Upper limits of weight gain }(\mathrm{kg}) & 10.1-42.0 & 10.1-25.4 & 10.3-42.0 \\ \text { \% Overweight in 1981/1988 } & 6.5 & 6.0 & 7.2 \\ \text { \% Overweight in 2002-2004 } & 73.8 & 78.5 & 67.6 \\ \text { \% Obese in 1981/1988 } & 0.8 & 0.7 & 0.9 \\ \text { \% Obese in 2002-2004 } & 18.8 & 14.8 & 24.3\end{array}$

2002-04 and participants were classified as normal weight, overweight $\left(25 \leq \mathrm{BMI}<30 \mathrm{~kg} / \mathrm{m}^{2}\right) \quad$ or obese $\left(\mathrm{BMI} \geq 30 \mathrm{~kg} / \mathrm{m}^{2}\right) .{ }^{11,12}$ Change in weight from average weight in 1981-88 over the 20-year follow-up was also determined. Substantial weight gain was defined as gaining $10 \mathrm{~kg}$ or more during the followup period. A $10 \mathrm{~kg}$ threshold was chosen as it represented the upper quartile of weight change in this sample.

\section{Covariates}

Information on a number of covariates was collected. Age, smoking status (current, former, or never) and frequency of alcohol consumption (more than once a day, 4 to 7 times a week, 1 to 3 times a week, 1 to 3 times a month, less than once a month, I don't drink alcohol) were obtained by questionnaire in 1981 and included as covariates in all models. Information on these covariates was coded differently in 1981 and 1988, so mean values could not be computed.

\section{Data analysis}

Logistic regression was used to predict overweight, obesity and substantial weight gain in 2002-04 from average BMI, physical activity and $\mathrm{VO}_{2 \max }$ from 1981-88 in the entire sample and in men and women separately. The predictor variables were included in the models as continuous, linear terms to preserve statistical power. Baseline (1981) age, smoking status, alcohol consumption, and sex (for analysis of overall group) were included as categorical covariates. Data management and analysis was conducted using SAS software (SAS Inc., Cary, NC).

\section{RESULTS}

During the 20-year time period of the study, the average BMI increased, and the prevalence of overweight and obesity also increased in the entire group and in each sex (Table I). Overall, 25.6\% of the sample gained $10 \mathrm{~kg}$ or more between 1981-88 and 2002-04, with $26.6 \%$ of men and 


\section{TABLE III}

Results of Logistic Regression of Mean Physical Activity, Mean $\mathrm{VO}_{2 \max }$ and Mean BMI in 1981 and 1988 Predicting Overweight $\left(25 \mathrm{~kg} / \mathrm{m}^{2} \leq \mathrm{BMI}<30 \mathrm{~kg} / \mathrm{m}^{2}\right)$, Obesity $\left(\mathrm{BMI} \geq 30 \mathrm{~kg} / \mathrm{m}^{2}\right)$ or $10 \mathrm{~kg}$ Weight Gain in 2002-04*

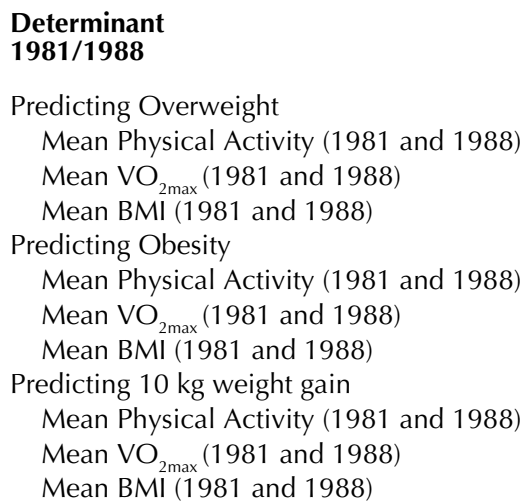

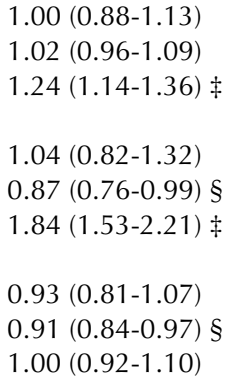

\author{
$1.08(0.93-1.25)$ \\ $1.05(0.97-1.14)$ \\ $1.25(1.10-1.41) \ddagger$ \\ $1.00(0.72-1.38)$ \\ $0.90(0.73-1.11)$ \\ $2.86(1.78-4.60) \ddagger$ \\ $0.95(0.81-1.12)$ \\ $0.96(0.88-1.05)$ \\ $1.04(0.92-1.18)$
}

\author{
$0.82(0.63-1.06)$ \\ $0.98(0.87-1.09)$ \\ $1.23(1.09-1.39) \ddagger$ \\ $0.99(0.64-1.53)$ \\ $0.86(0.71-1.04)$ \\ $1.57(1.27-1.94) \ddagger$ \\ $0.87(0.66-1.15)$ \\ $0.82(0.72-0.93) \S$ \\ $0.96(0.85-1.09)$
}

* Units for predictor variables are provided in Table I.

** Adjusted for age, sex, smoking, alcohol consumption.

$\dagger$ Adjusted for age, smoking and alcohol consumption.

$\neq p<0.001$.

$\S \mathrm{p}<0.05$.

All odds ratios are also adjusted for all other variables in the model (i.e., mean physical activity, mean $\mathrm{VO}_{2}$ mean BMI).

$24.6 \%$ of women experiencing this weight gain (Table II). Within the $10 \mathrm{~kg}$-plus weight gain group, there was an overall gain of 14.8 (SD: 4.5$) \mathrm{kg}$, with men gaining an average of 13.9 (SD 3.3) $\mathrm{kg}$ and women gaining 15.6 (SD: 5.3$) \mathrm{kg}$.

Higher $\mathrm{VO}_{2 \max }$ in the overall group was associated with lower odds of obesity in 2002-04 (Table III), independent of average BMI and physical activity, and baseline age, sex, smoking and alcohol consumption. There were no significant relationships between $\mathrm{VO}_{2 \max }$ in 1981-88 and being overweight in 2002-04, or between physical activity in 1981-88 and being overweight or obese in 2002-04 (Table III). It was also found that higher average BMI in 1981-88, independent of average $\mathrm{VO}_{2 \max }$, and average physical activity was a significant predictor of overweight or obesity in 2002-04 (Table III). Indeed, higher average BMI in 1981-88 in men was a strong predictor of being obese in 200204.

Higher levels of $\mathrm{VO}_{2 \max }$ resulted in lower odds of gaining $10 \mathrm{~kg}$ or more weight in the overall group during the follow-up period (Table III). Sex-specific analyses demonstrated that in women only, higher levels of $\mathrm{VO}_{2 \max }$ resulted in lower odds of a $10 \mathrm{~kg}$ weight gain (Table III).

A separate analysis of the presence of overweight in 1981 predicting the development of obesity in 2002-04 indicated that being overweight was a significant predictor of future obesity compared to those who were not overweight or obese in 1981, independent of average $\mathrm{VO}_{2 \max }$, physical activity and baseline age, alcohol consumption, income and smoking (total sample OR: 9.1, 95\% CI: 4.3-19.2; men OR: 22.2, 95\% CI: 5.0-98.0; women OR: 5.4, 95\% CI: 2.0-14.4).

\section{DISCUSSION}

In this 20-year longitudinal study, low levels of cardiorespiratory fitness were associated with a higher future risk of obesity, independent of baseline age, physical activity, BMI, sex, smoking status and alcohol consumption. Women with higher levels of cardiorespiratory fitness were also less likely to experience a weight gain of $10 \mathrm{~kg}$ or more over the follow-up period. Furthermore, those with higher average BMI in 1981-88 were more likely to be overweight or obese in 2002-04.

Others have investigated the relationships between physical fitness, physical activity and weight gain or the development of overweight or obesity over time. DiPietro and colleagues found that in middle-aged men, only those who improved their fitness level over time had less agerelated weight gain, ${ }^{13}$ whereas Bailey et al. found that lower $\mathrm{VO}_{2 \max }$ levels in men were associated with an increased probability of being overweight or obese over 20 years. ${ }^{14}$ With respect to physical activity, Williamson et al. reported that baseline recreational physical activity levels had no relationship to the relative odds of gaining weight during a 10 -year follow-up. ${ }^{5}$ Indeed, Petersen et al. found a similar lack of relationship between physical activity and development of obesity. ${ }^{6}$

In the current investigation, significant results were found for cardiorespiratory fitness but not for physical activity. This may be due, in part, to differences in the accuracy and reliability of measurement between the two variables. Physical activity is a complex behaviour that is difficult to assess. ${ }^{15}$ It is most often measured using self-reported questionnaires and thus has greater error associated with it. In contrast, physical fitness is a biological trait that is more reliably measured. Indeed, it has been suggested that physical fitness is a better marker of true habitual physical activity than measurements of physical activity. ${ }^{16}$ Thus, that our self-reported measure of physical activity was not consistently found to be a significant predictor of obesity might be in part due to its being a less reliable measurement than physical fitness.

Significant relationships were found between baseline BMI (average 1981-88) and the development of obesity. Those with higher BMI had greater odds of being overweight or obese 20 years later, and those who were already overweight at baseline were more likely to be obese in the final phase. Similar results were found in the longitudinal National Population Health Survey where overweight individu- 
als in 1994/95 had an elevated risk of becoming obese in 2002-03. ${ }^{17}$ These findings demonstrate the stability of body weight over time and that once weight is gained, it may lead to further weight gain. From a public health perspective, the results suggest that targeting overweight individuals for obesity prevention programs may have added value.

The results show independent effects for physical fitness and BMI; thus, both are important in the prediction of future obesity. Beyond the effects on body weight we have demonstrated, physical fitness has a protective effect against premature mortality in normal weight, overweight and obese men. ${ }^{18}$ Thus, higher levels of physical fitness are beneficial regardless of body weight status. This reinforces the notion that physical activity should be promoted at all levels of body weight.

There are several strengths and limitations of the current study. The PALS database is a unique cohort that is representative of the Canadian population for which information regarding physical activity, fitness, health indicators and socio-environmental factors were collected over a 20 -year period. ${ }^{9}$ The longitudinal nature of the study is a marked strength, which allows for the study of physical activity and health in Canadians from 1981 to 2002-04. Furthermore, the PALS database contains measured values for height, weight, and cardiorespiratory fitness in 1981 and 1988. There is currently a lack of directly measured health information in Canada, ${ }^{19}$ and this study made use of this valuable resource. On the other hand, a limitation of this investigation was the lack of measured data in the final phase of the study (2002-04). Self-reported measures such as those for physical activity and BMI are subject to bias and misinterpretation. In particular, the self-reported nature of height and weight may have resulted in an underestimation of the prevalence of obesity and of those who gained weight.

In conclusion, cardiorespiratory fitness and BMI were important predictors of weight gain and obesity in this sample of Canadians. Higher levels of cardiorespiratory fitness were associated with a lower risk of future obesity, independent of baseline BMI. Women with higher levels of cardiorespiratory fitness were less likely to experience a weight gain of $10 \mathrm{~kg}$ or more.
On the other hand, higher BMI was associated with a higher odds of obesity, highlighting the stability of adiposity over time. Strategies to identify individuals at an increased risk of weight gain and obesity should include measurements of both body weight status and physical fitness.

\section{REFERENCES}

1. Tjepkema M. Measured Obesity. Adult Obesity in Canada: Measured Height and Weight. Statistics Canada 2005; Nutrition: Findings from the Canadian Community Health Survey. Catalogue no. 82-620-MWE2005001.

2. Katzmarzyk PT, Janssen I. The economic costs associated with physical inactivity and obesity in Canada: An update. Can J Appl Physiol 2004;29:90-115.

3. Katzmarzyk PT, Ardern CI. Overweight and obesity mortality trends in Canada, 1985-2000. Can J Public Health 2004;95:16-20.

4. Swinburn B, Egger G. The runaway weight gain train: Too many accelerators, not enough brakes. BMJ 2004;329:736-39.

5. Williamson DF, Madans J, Anda RF, Kleinman JC, Kahn HS, Byers T. Recreational physical activity and ten-year weight change in a US national cohort. Int J Obes Relat Metab Disord 1993;17:279-86

6. Petersen L, Schnohr P, Sorensen TIA. Longitudinal study of the long-term relation between physical activity and obesity in adults. Int J Obes Relat Metab Disord 2004;28:105-12.

7. Paffenbarger RS, Jr., Blair SN, Lee I-M, Hyde RT. Measurement of physical activity to assess health effects in free-living populations. Med Sci Sports Exerc 1993;25:60-70.

8. Katzmarzyk PT, Perusse L, Malina RM, Bouchard C. Seven year stability of indicators of obesity and adipose tissue distribution in the Canadian population. Am J Clin Nutr 1999;69:1123-29.

9. Craig C, Gauvin L, Cragg S, Katzmarzyk PT, Stevens T, Storm RJ, et al. Towards a social epidemiological perspective on physical activity and health: The aims, design and methods of the Physical Activity Longitudinal Study (PALS). J Phys Act Health 2005;3:272-84.

10. Fitness Canada. Fitness and lifestyle in Canada: A Report by the Canada Fitness Survey. 1983.

11. World Health Organization. Obesity: Preventing and managing the global epidemic. Report of a WHO Consultation on Obesity, 1998.

12. Health Canada. Canadian guidelines for body weight classification in adults. 2003. Available online at: http://www.hc-sc.gc.ca/fn-an/ alt_formats/hpfb-dgpsa/pdf/nutrition/weight book-livres_des_poids_e.pdf (Accessed February 5, 2007).

13. DiPietro L, Kohl III HW, Barlow CE, Blair SN. Improvements in cardiorespiratory fitness attenuate age-related weight gain in healthy men and women: The Aerobics Center Longitudinal Study. Int J Obes Relat Metab Disord 1998;22:5562.

14. Bailey MW, Schubert CM, Wentling VJ Wurzbacher KA, Czerwinski SA, Demerath EW, et al. Cardiorespiratory fitness during adulthood and CVD risks twenty years later: The Fels Longitudinal Study. Med Sci Sports Exerc 2003:35:S71.

15. Wareham NJ, Rennie KL. The assessment of physical activity in individuals and populations: Why not try to be more precise about how physical activity is assessed? Int J Obes Relat Metab Disord 1998;22:S30-S38.

16. Blair SN, Jackson AS. Physical fitness and activity as separate heart disease risk factors: A metaanalysis. Med Sci Sports Exerc 2001;33:762-64.

17. Le Petit C, Bethelot J-M. Healthy today, healthy tomorrow? Findings from the National Population Health Survey; Obesity: A Growing Issue. 2005; Component of Statistics Canada Catalogue no. 82-618-MWE2005003.

18. Wei M, Kampert JB, Barlow CE, Nichman MZ, Gibbons LW, Paffenbarger RS, et al. Relationship between low cardiorespiratory fitness and mortality in normal-weight, overweight, and obese men. JAMA 1999;282:1547-53.

19. Tremblay M. The need for directly measured health data in Canada. Can I Public Health 2004;95:165-66.

Received: March 14, 2006

Accepted: October 16, 2006

\section{RÉSUMÉ}

Contexte : L'obésité est un problème de santé de plus en plus présent au Canada, d'où I'importance d'en définir les déterminants pour élaborer des stratégies de prévention. L'objet de notre enquête était de déterminer les liens entre l'activité physique, l'endurance cardiorespiratoire, I'indice de masse corporelle (IMC) et l'obésité future.

Méthode : Notre échantillon de 459 adultes (18 ans et plus; 223 hommes, 236 femmes) était tiré de I'Enquête condition physique Canada (2002-2004). Les données sur l'activité physique, le tabagisme, la consommation d'alcool, l'IMC et l'endurance cardiorespiratoire (test $\mathrm{VO}_{2}$ ) ont été recueillies en 1981 et en 1988. Nous avons calculé les moyennes de l'IMC, de l'activité physique et du $\mathrm{VO}_{2 \max }$ des enquêtes de 1981 et de 1988. D'après les données sur la taille et le poids déclarées par les intéressés dans l'enquête de 2002-2004, nous avons classé les participants comme étant obèses (IMC $\geq 30 \mathrm{~kg} / \mathrm{m}^{2}$ ) ou faisant de l'embonpoint (IMC de 25 à $29,9 \mathrm{~kg} / \mathrm{m}^{2}$ ). Au moyen d'une analyse de régression logistique, nous avons prédit le surpoids, l'obésité ou les gains de poids importants (10 kg et plus) en 2002-2004, après avoir apporté des ajustements pour tenir compte des effets de l'âge, du sexe, du tabagisme et de la consommation d'alcool.

Résultats : Un $\mathrm{VO}_{2 \max }$ élevé en 1981-1988 était associé à une faible probabilité d'obésité en 2002$2004(R C=0,87 ;$ I I C de $95 \%$ =0,76-0,99, p<0,05), et un IMC élevé en 1981-1988 était associé à une probabilité d'obésité élevée en 2002-2004 (1,84; 1,52-2,20, p<0,0001). Chez les femmes, un $\mathrm{VO}_{2 \text { max }}$ élevé $(0,82 ; 0,72-0,93)$ a entraîné une faible probabilité de gain de poids de 10 kg ou plus.

Conclusion : Ces résultats montrent que l'endurance cardiorespiratoire et l'IMC antérieur sont d'importants prédicteurs du gain de poids et de l'obésité futurs; il faudrait donc en tenir compte dans les stratégies ciblant les personnes qui présentent un risque d'obésité accru. 